\title{
Detection of anthraquinones and identification of 1,4-naphthohydroquinone in cell suspension cultures of Rudgea jasminoides (Cham.) Müll. Arg. (Rubiaceae)
}

\author{
MARISA DE CACIA OLIVEIRA ${ }^{1}$, GIUSEPINA NEGRI ${ }^{2}$, ANTÔNIO SALATINO² and \\ MÁRCIA REGINA BRAGA ${ }^{3,4}$
}

(received: May 11, 2006; accepted: February 8, 2007)

\begin{abstract}
Detection of anthraquinones and identification of 1,4-naphthohydroquinone in cell suspension cultures of Rudgea jasminoides (Cham.) Müll. Arg. (Rubiaceae)). In Rubiaceae, anthraquinones and naphthoquinones are secondary metabolites characteristic of the subfamily Rubioideae, in which Rudgea jasminoides is included. Thin-layer chromatography using specific solvent systems and spray reagents indicated the presence of anthraquinones constitutively produced by cell suspension cultures of $R$. jasminoides. GC/MS analysis detected 1,4-naphthohydroquinone as a product of biosynthesis only after elicitation of the cells with yeast extract (Saccharomyces cerevisiae). The latter compound is probably a phytoalexin produced by suspension cultures of $R$. jasminoides.
\end{abstract}

Key words - cell suspension culture, elicitor, naphtoquinones, Rubiaceae

RESUMO - (Detecção de antraquinonas e identificação de 1,4-naftohidroquinona em suspensões celulares de Rudgea jasminoides (Cham.) Müll. Arg. (Rubiaceae)). Em Rubiaceae, antraquinonas e naftoquinonas são metabólitos secundários que caracterizam quimicamente a subfamília Rubioideae, na qual Rudgea jasminoides é incluída. Análises por cromatografia em camada delgada usando sistemas de solventes e reveladores específicos indicaram a presença de antraquinonas sintetizadas constitutivamente por suspensões celulares de R. jasminoides. Análises de GC/MS detectaram a presença de 1,4-naftohidroquinona como produto de biossíntese apenas após a eliciação das células com extrato de leveduras (Saccharomyces cerevisiae). Esta substância é provavelmente uma fitoalexina produzida por suspensões celulares de R. jasminoides.

Palavras-chave - eliciador, naftoquinonas, Rubiaceae, suspensão celular

\section{Introduction}

The utilization of plant cell suspension cultures has gained increasing attention over the past decades, aiming the large-scale production of plant-derived natural products, mainly secondary metabolites (Komaraiah et al. 2005). A number of plant species have been used for generation and propagation of cell-suspension cultures, ranging from model systems like Taxus (Jha et al. 1998), Arabidopsis (Richard et al. 2001) and Catharanthus (Kim et al. 2004) to important monocotyledon or dicotyledon crop plants like soybean

1. Universidade Tecnológica Federal do Paraná, Campus Pato Branco, Caixa Postal 571, 85503-390 Pato Branco, PR, Brazil.

2. Universidade de São Paulo, Departamento de Botânica, Caixa Postal 11461, 05422-970 São Paulo, SP, Brazil.

3. Instituto de Botânica, Seção de Fisiologia e Bioquímica de Plantas, Caixa Postal 3005, 01061-97 São Paulo, SP, Brasil.

4. Corresponding author: bragamr@ig.com.br
(Chu \& Lark 1976), alfalfa (Atanassov \& Brown 1984), rice (Lee et al. 2004), and tobacco (Hellwig et al. 2004).

In spite of the potential application of plant-cellsuspension cultures in biotechnology to produce naturally occurring secondary metabolites, successful production with yields surpassing those obtained from whole plants is rare. Members of the Rubiaceae are among the few plant families easily taken into cell cultures to produce substantial amounts of secondary products (Abdullah et al. 1998). The optimization of medium and culture conditions led to accumulation of secondary metabolites that exceed those of differentiated tissues in seventeen species belonging to the genera Asperula, Rubia, Sherardia (Schulte et al. 1984), and in some species of Morinda (Abdullah et al. 1998, Komaraiah et al. 2005).

Of particular interest has been the metabolism and production of anthraquinones in Rubiaceae cell cultures. Anthraquinones are a class of natural products encompassing several hundreds of compounds, differing in the nature and positions of substituent groups 
(Schripsema et al. 1999). They are common constituents of Rubiaceae, being accumulated mainly in roots, leaves and fruits of species belonging to the Rubioideae subfamily, for which they were shown to be useful chemotaxonomic markers (Young et al. 1996). Many anthraquinones have potential therapeutic value, since antimicrobial, insecticidal, antitumor, anticongestive, hypotensive and sedative properties have been assigned to these compounds (Abdulllah et al. 1998, Komaraiah et al. 2005 and refs therein).

Rudgea jasminoides (Cham.) Müll. Arg. (Rubiaceae) is a woody species of the Rubioideae subfamily, being native in the Atlantic Forest of southeastern and southern Brazil (Zappi 2003). A survey of phytoalexin production in plants in the tropical environment pointed out $R$. jasminoides as a promising source of induced highly fungitoxic secondary metabolites (Braga et al. 1986). When growing in the natural environment, the phytoalexin response of this species is dependent on seasonal conditions (Braga et al. 1991).

Defensive responses of woody plant species have been under-studied due to difficulties of working with whole plant material and controlling the environmental conditions. In the natural environment, $R$. jasminoides can reproduce through seed, while attempts to sexually propagate the plant under greenhouse conditions were unsuccessful. Cell suspension cultures of $R$. jasminoides were successfully obtained from callus derived from petiole explants (Stella \& Braga 2002). This material was shown to be a good system for studying the induction of phytoalexins under controlled conditions (Oliveira 2005). In this paper, we describe the detection of constitutive anthraquinones and an induced naphthohydroquinone in cell suspension cultures of this Rubiaceae species, which are absent in extracts of in vivo growing plants.

\section{Material and methods}

Plant material - Young leaves of Rudgea jasminoides (Rubiaceae) were collected from plants growing naturally in the forest of the "Reserva Biológica do Parque Estadual das Fontes do Ipiranga" (2339' S, 46 38' W), state of São Paulo, SP, Brazil. A voucher specimen was registered at the Herbarium Eneida P.K. Fidalgo, SP(SP161348), Brazil.

Cell suspension cultures - Cells of $R$. jasminoides were obtained from friable calluses derived from petiole explants (Stella \& Braga 2002) and maintained in $125 \mathrm{~mL}$-Erlenmeyer flasks containing $30 \mathrm{~mL}$ of the medium supplemented with $8.28 \mu \mathrm{M}$ Picloram (4-amino-3, 5,6-trichloropicolinic acid). The media used consisted of half-strength nitrogen MS medium
(Murashige \& Skoog 1962) modified by the addition of $0.55 \mu \mathrm{M}$ myo-inositol, $0.31 \mu \mathrm{M}$ thiamine- $\mathrm{HCl}, 8 \mathrm{nMnicotinic}$ acid and $5 \mathrm{nM}$ pyridoxine- $\mathrm{HCl}, 0.82 \mu \mathrm{M}$ cysteine, $5 \%$ coconut water and $87.6 \mu \mathrm{M}$ sucrose. The $\mathrm{pH}$ was adjusted to 5.8 and the media were autoclaved for $20 \mathrm{~min}$ at $121^{\circ} \mathrm{C}$ at $0.152 \mathrm{M} \mathrm{Pa}$. The cell suspension cultures were maintained in orbital shaker $\left(100\right.$ cycles $\left.\min ^{-1}\right)$ at $26 \pm 2{ }^{\circ} \mathrm{C}$ under $12 \mathrm{~h}$ photoperiod with irradiance of $50 \mu \mathrm{mol} \mathrm{m}^{-2} \mathrm{~s}^{-1}$ at culture level. Subculturing was performed by transferring approximately $0.5 \mathrm{~g}$ of fresh cells from the exponential growth phase (15 d-old cultures) to $125 \mathrm{~mL}$-Erlenmeyer flasks with $30 \mathrm{~mL}$ of the same medium. For all experiments, at least three replicates per treatment were carried out.

Elicitor preparation - Commercial yeast extract (Fermix) was suspended in distilled water $\left(100 \mathrm{mg} \mathrm{mL}^{-1}\right)$ and autoclaved for $15 \mathrm{~min}$ at $121{ }^{\circ} \mathrm{C}$ and $0.152 \mathrm{MPa}$. The autoclaved extract was centrifuged $\left(3,000 \mathrm{rpm}, 15 \mathrm{~min}\right.$, at $\left.25{ }^{\circ} \mathrm{C}\right)$ and the supernatant quantified to total sugars according to Dubois et al. (1956), using glucose as standard. A solution containing $1 \mathrm{mg}$ glucose equivalents $\mathrm{mL}^{-1}$ was used as elicitor.

Elicitation assays - Disks of freshly harvested young leaves of $R$. jasminoides were disinfected with sodium hypochlorite ( $0.75 \%$ chlorine) for $15 \mathrm{~min}$ and washed in autoclaved distilled water. Drops of $50 \mu \mathrm{L}$ of the elicitor solution or distilled water (control) were placed on the adaxial surface of the disks and these were incubated under water vapor saturated atmosphere at $25{ }^{\circ} \mathrm{C}$ in the darkness for $48 \mathrm{~h}$ (Dietrich et al. 1987). The leaf disks were then assayed for the presence of anthraquinones as described below. Cell suspension cultures of $R$. jasminoides were cultivated for nine days as described above and subsequently treated with $1 \mathrm{~mL}$ (containing $1 \mathrm{mg}$ equivalent of glucose) of the yeast elicitor or $1 \mathrm{~mL}$ of distilled water (control) and incubated for 96, 168 or 240 hours prior to the assays for detection of anthraquinones.

Anthraquinone and naphtoquinone detection - Metabolites were extracted from elicited and control leaf disks by immersing twice in ethyl acetate ( $10 \mathrm{~mL}$ per $\mathrm{g}$ fresh weight), and gently shaking for $4 \mathrm{~h}$ at room temperature. The material was filtered and the filtrate dried under reduced pressure. The residue was dissolved in ethyl acetate ( $1 \mathrm{~mL}$ per $\mathrm{g}$ fresh weight) and $50 \mu \mathrm{L}$ of the extracts submitted to thin layer chromatography (TLC) on silica gel plates Merck developed with petrol ether:ethyl acetate:formic acid (75:25:1 v/v/v) or toluene:formic acid $(99: 1 \mathrm{v} / \mathrm{v})$. Anthraquinones were visualized by spraying with $10 \% \mathrm{KOH}$ in ethanol and naphthoquinones with $10 \%$ $\mathrm{KOH}$ in methanol (Wagner \& Bladt 1986). Cells from suspension cultures, control or treated with yeast elicitor for different periods were harvested by filtration and submitted to the same procedures for metabolites extraction and TLC analysis. The culture media were extracted twice with the same volume of ethyl acetate and the extracts also assayed for the presence of anthraquinones and naphthoquinones. The contents of anthraquinones in the cells were estimated according to Schulte et al. (1984). The residues of the ethyl acetate extracts were dissolved in $80 \%$ ethanol and the 
absorbance measured at $410 \mathrm{~nm}$, using the alizarin molar extinction coefficient $(55,000)$.

GC/MS analysis - Extracts of control and elicited cells were also analyzed by gas chromatography coupled with mass spectrometry. Dried samples were methylated according to Vogel (1971) and dissolved in ethyl ether. EIMS data were obtained with a Hewlett Packard gas chromatograph 5890 Series II Plus, interfaced with a Hewlett Packard 5989B mass spectrometer operating at an ionization voltage of $70 \mathrm{eV}$. One $\mathrm{mL}$ of an ethyl ether solution was injected into the gas chromatograph. An HP-5 fused silica capillary column (30 m $\times$ $0.25 \mathrm{~mm}$ ), mass selective detector, He as carrier gas at $32 \mathrm{~cm} \mathrm{~min}^{-1}$ and split ratio 1:10 were used. Oven temperatures ranged from 100 to $300{ }^{\circ} \mathrm{C}$ at $10{ }^{\circ} \mathrm{C} \mathrm{min}{ }^{-1}$, ending with an isothermal period of 15 minutes. Injector and detector temperatures were $300{ }^{\circ} \mathrm{C}$. Identification of 1,4-naphthohydroquinone was based on analysis of the corresponding mass spectrum and comparison with data of the Wiley-275 library.

Antifungal activity assay - Leaf and cell extracts were submitted to bioautography for the detection of antifungal compounds. The extracts were analyzed by TLC using silica gel and chloroform:methanol (99:1 v/v). The chromatogram was sprayed with a spore suspension of the fungus Cladosporium sphaerospermum as described by Homans \& Fuchs (1970).

\section{Results and Discussion}

Cells of Rudgea jasminoides cultivated in liquid medium produce constitutive anthraquinones, their accumulation increasing during the exponential growth phase from 13 to 19 days of cultures (figure 1). These metabolites are absent in leaf extracts of plants growing under environmental conditions (figure 1A) as well as in calli grown on solid medium (not shown). Although anthraquinones are commonly found in members of Rubiaceae, their production in tissue cultures does not follow a general pattern (Schulte et al. 1984). In Cinchona pubescens, for instance, these metabolites were detected in cultured cells prior elicitation (Wijnsma et al. 1984), as we observed for $R$. jasminoides. In contrast, cells of Cinchona robusta accumulated anthraquinones only after treatment with fungal elicitors (Schripsema et al. 1999).

As previously reported for other anthraquinoneproducing cell cultures of Rubiaceae, a yellow-orange coloration in the medium was observed in elicitor-treated cells of $R$. jasminoides (not shown). This color has been attributed to anthraquinone formation (Schripsema et al. 1999). Indeed, addition of the yeast elicitor to the cultures of $R$. jasminoides enhanced anthraquinone biosynthesis (figure 1B). No significant effect in

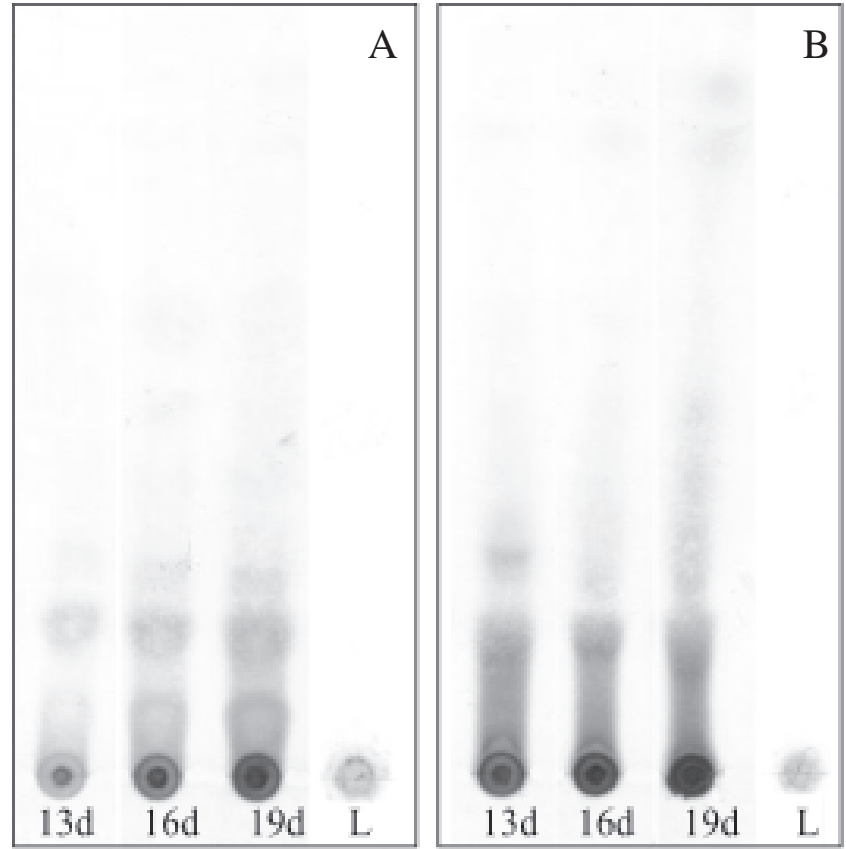

Control

Elicited

Figure 1. Detection of anthraquinones in leaves and in cells of Rudgea jasminoides cultivated in suspension. Nine-day-old cells were incubated for 96, 168 and 240 hours with water (control) (A) or yeast elicitor (elicited) (B), representing 13, 16 and 19 days of cultivation, respectively. Leaves (L) were incubated with water or yeast elicitor for 48 hours. Petrol ether: ethyl acetate: formic acid (75:25:1 v/v/v) was used as solvent system and the anthraquinones were visualized by spraying $10 \% \mathrm{KOH}$ in ethanol.

anthraquinone accumulation was observed extending the incubation period from 96 to 240 hours. Again, these metabolites were not detected in elicitor-treated leaves of the plant growing in natural conditions (figure 1B).

The treatment of 9-day-old cultures of $R$. jasminoides with yeast elicitor had a slight effect on cell growth (figure $2 \mathrm{~A}$ ). The quantification of anthraquinones using the molar extinction coefficient of alizarin revealed that, under our experimental conditions, higher yields of anthraquinones were reached after elicitation, resulting in a $c a .2 .5$ fold increase for cultures in the middle of the exponential growth phase (figure 2B). Increase of anthraquinone content also occurs as a consequence of culture aging, being observed a ca. 6-fold increase from 9 to 13 days of in vitro growth (figure 2B). The anthraquinone content of $R$. jasminoides cells was similar to that described for Cinchona robusta, which produce considerable amounts of these metabolites after elicitation (Han et al. 2002). 

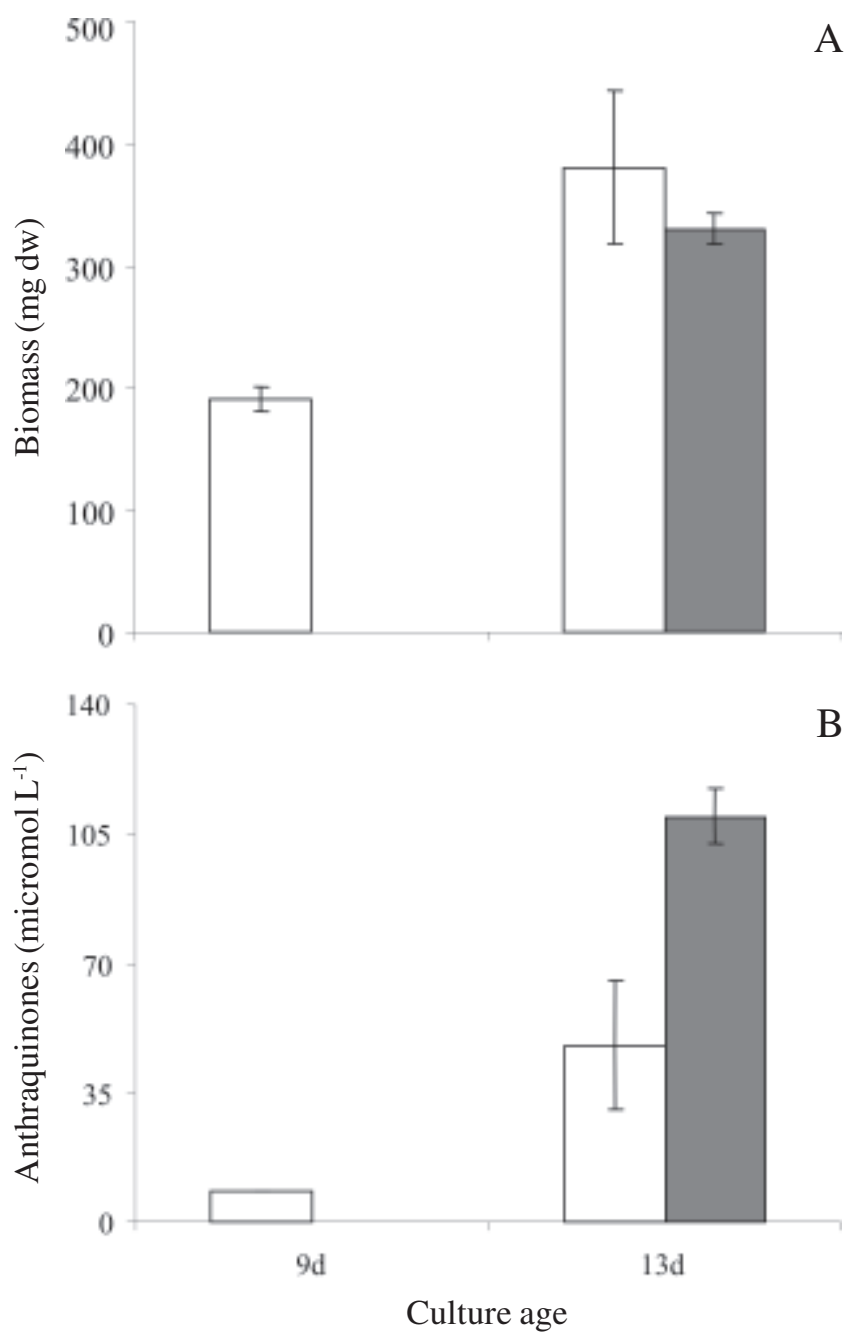

Figure 2. Dry mass (A) and anthraquinone content (B) in cell suspension of Rudgea jasminoides cultured 9 days (9d) or incubated for 96 hours (13d) with water ( $\square$ ) or yeast elicitor ( $\square$ ). Bars represent the standard deviations of the means of triplicates.

Naphthoquinone aglycones were detected by specific chromatogram staining only from elicited cells (figure 3A) with different culture ages, suggesting that such compounds may act as stress metabolites or phytoalexins as previously reported by Wijnsma et al. (1985). By bioautography, intense antifungal activity was detected for spots corresponding to the Rfs of the induced naphthoquinones. However, inhibitory compounds from control cells with similar Rfs were also observed, indicating that fungitoxicity may be accounted for substances other than the induced naphthoquinones. Moreover, other compounds with fungitoxic activity are present in cells suspension cultures of $R$. jasminoides, some of them being enhanced or induced by treatment with yeast elicitor (figure 3B). Considering that

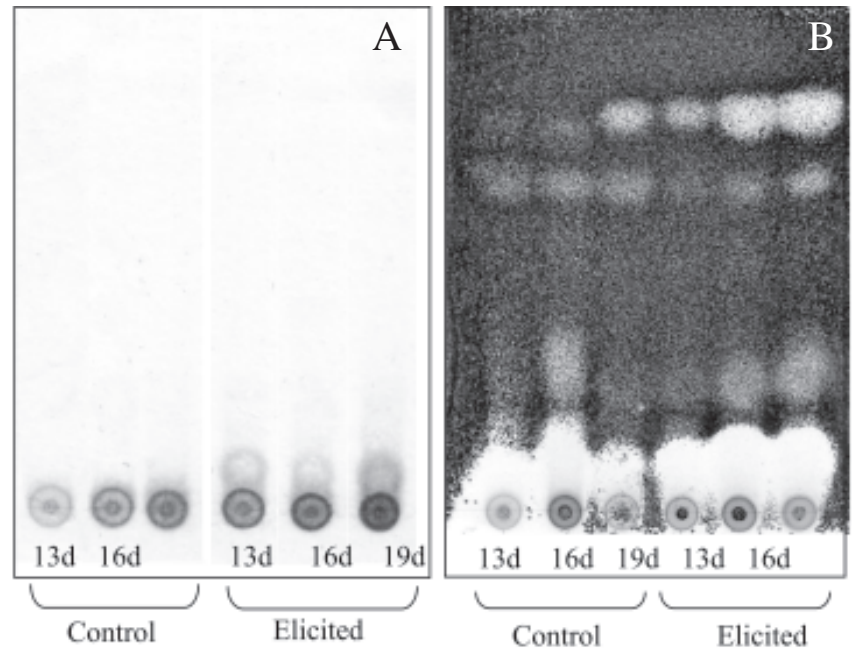

Figure 3. Detection of naphthoquinones (A) in cells of Rudgea jasminoides cultivated in suspension. Nine-day-old cells were incubated for 96, 168 and 240 hours with water (control) or yeast elicitor (elicited), representing 13,16 and 19 days (d) of cultivation, respectively. Toluene: formic acid (99:1 $\mathrm{v} / \mathrm{v}$ ) was used as solvent system and the naphthoquinones were visualized by spraying with $10 \% \mathrm{KOH}$ in methanol. Bioautography of the same extracts (B) using spores of Cladosporium sphaerospermum. White spots represent the inhibition of fungal growth.

fungitoxic compounds were found in leaf extracts before and after elicitation and that anthraquinones and naphthoquinones were not detect therein, such $R$. jasminoides quinones might well be stress compounds synthesized exclusively in in vitro cultures. Anthraquinones produced by Cinchona spp. tissue cultures were assumed to be phytoalexins, since they were not detected in extracts from non-induced plants (Wijnsma et al. 1985).

Elicitation seemingly leads to a substantial change in the production of anthraquinones and similar compounds by $R$. jasminoides cell cultures. In fact, very distinct chromatograms resulted through GC analyses of extracts from control and elicited cultures, the former produced more compounds, which may be detected with the analysis conditions (data not shown). A compound with retention time 7.718 min obtained from elicited cultures corresponds to 1,4naphthohydroquinone (1,4-naphthalenediol), as indicates the high similarity between its mass spectrum and that of the authentic sample in Wiley-275 library. Mass spectral data of the compound are: $(\mathrm{m} / \mathrm{z}) 160$ $\left(\mathrm{M}^{+}, 66 \%, \mathrm{C}_{10} \mathrm{O}_{2} \mathrm{H}_{8}^{+}\right), 131\left(29 \%, \mathrm{C}_{9} \mathrm{OH}_{7}^{+}\right), 104(100 \%$, $\left.\mathrm{C}_{7} \mathrm{OH}_{4}^{+}\right), 76\left(59 \%, \mathrm{C}_{6} \mathrm{H}_{4}{ }^{+}\right)$(see figure 4 for structures of the relevant fragments). 
In conclusion, our data indicate that cell suspensions of $R$. jasminoides produce anthraquinones, but elicitation of the same cells leads to the production of manycompounds, one of them being 1,4naphthohydroquinone, probably a phytoalexin.<smiles>Oc1ccc(O)c2ccccc12</smiles>

$\mathrm{m} / \mathrm{z}=\mathbf{1 6 0}$

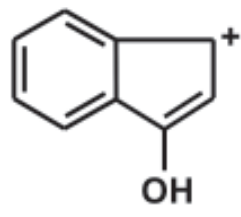

$\mathrm{m} / \mathrm{z}=131$

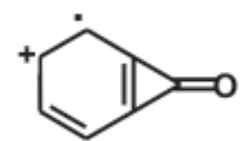

$\mathrm{m} / \mathrm{z}=104$

Figure 4. Proposed structures of relevant fragments corresponding to the mass spectra of 1,4dihydronaphtoquinone, detected as the peak with 7.718 min of elution in the chromatogram (GC/MS analysis) of the yeast-elicited cells of Rudgea jasminoides.

Acknowledgements - Thanks are due to CAPES (Brazil) for the fellowship to M.C. Oliveira, to CNPq (Brazil) for the research fellow grant to M.R. Braga, and to FAPESP for grant to the project (FAPESP, 98/ 05124-8, BIOTA/SP, Brazil).

\section{References}

ABDULLAH, M.A., ALI, A.M., MARZIAH, M., LAJIS, N.H. \& ARIFF, A.B. 1998. Establishment of cell suspension cultures of Morinda elliptica for the production of anthraquinones. Plant Cell, Tissue and Organ Culture 54:173-182.

ATANASSOV, A. \& BROWN, D.C.W. 1984. Plant regeneration from suspension culture and mesophyll protoplasts of Medicago sativa L. Plant Cell, Tissue and Organ Culture 3:149-162.

BRAGA, M.R., YOUNG, M.C.M., PONTE, J.V.A., DIETRICH, S.M.C., EMERENCIANO, V.D. \& GOTTLIEB, O.R. 1986. Phytoalexin induction in plants of tropical environment. Biochemical, Systematics and Ecology 14:507-514.

BRAGA, M.R., YOUNG, M.C.M., DIETRICH, S.M.C. \& GOTTLIEB, O.R. 1991. Phytoalexin induction in Rubiaceae. Journal of Chemical Ecology 17:1079-1090.

CHU, Y. \& LARK, K.G. 1976. Cell-cycle parameters of soybean (Glycine $\max$ L.) cells growing in suspension culture: suitability of the system for genetic studies. Planta 132:259-268.

DIETRICH, S.M.C., YOUNG, M.C.M, MAXIMIUCNACCACHE, V., BRAGA, M.R. \& GOTTILIEB, O.R. 1987. Fitoalexinas. Ciência e Cultura 39:149-152.

DUBOIS, M., GILLES, A., HAMILTON, J.K., REBERS, P.A. \& SMITH, F. 1956. Colorimetric method for determination of sugars and related substances. Analytical Chemistry 28:350-355.
HAN, Y.-S., HEIJDEN, R. \& VERPOORTE, R. 2002. Improved anthraquinone accumulation in cell cultures of Cinchona 'Robusta' by feeding of biosynthetic precursors and inhibitors. Biotechnology Letters 24:705-710.

HELLWIG, S., DROSSARD, J., TWYMAN, R.M. \& FISCHER, R. 2004. Plant cell cultures for the production of recombinant proteins. Nature Biotechnology 22:1415-1422.

HOMANS, A.L. \& FUCHS, A. 1970. Direct bioautography on thin-layer chromatograms as a method for detecting fungitoxic substances. Journal of Chromatography 51:327-329.

JHA, S., SANYAL, D., GHOSH, B. \& JHA, T.B. 1998. Improved taxol yield in cell suspension culture of Taxus wallichiana (Himalayan yew). Planta Medica 64:370-372.

KIM, S.W., IN, D.S., CHOI, P.S. \& LIU, J.R. 2004. Plant regeneration from immature zygotic embryo-derived embryogenic calluses and cell suspension cultures of Catharanthus roseus. Plant Cell, Tissue and Organ Culture 76:131-135.

KOMARAIAH, P., KISHOR, P.B.K., CARLSSON, M., MAGNUSSON, K.-E. \& MANDENIUS, C.-F. 2005. Enhancement of anthraquinone accumulation in Morinda citrifolia suspension cultures. Plant Science 168:1337-1334.

LEE, T.-J., SHULTZ, R.W., HANLEY-BOWDOIN, L. \& THOMPSON, W.F. 2004. Establishment of rapidly proliferating rice cell suspension culture and its characterization by fluorescence-activated cell sorting analysis. Plant Molecular Biology Reporter 22:259-267.

MURASHIGE, T. \& SKOOG, F. 1962. A revised medium for rapid growth and bioassays with tobacco tissue cultures. Physiologia Plantarum 15:473-497.

OLIVEIRA, M.C. 2005. Indução da síntese de substâncias antifúngicas em suspensões celulares de Rudgea jasminoides (Rubiaceae). Tese de doutorado, Universidade de São Paulo, São Paulo.

RICHARD, C., GRANIER, C., INZÉ, D. \& De VEYLDER, L. 2001. Analysis of cell division parameters and cell cycle gene expression during the cultivation of Arabidopsis thaliana cell suspensions. Journal of Experimental Botany 52:1625-1633.

SCHRIPSEMA, J., RAMOS-VALDIVIA, A. \& VERPOORTE, R. 1999. Robustaquinones, novel anthraquinones from elicited Cinchona robusta suspension culture. Phytochemistry 51:55-60.

SCHULTE, U., EL-SHAGI, H. \& ZENK, M.H. 1984. Optimization of 19 Rubiaceae species in cell culture for the production of anthraquinones. Plant Cell Reports 3:51-54.

STELLA, A. \& BRAGA, M.R. 2002. Callus and cell suspension cultures of Rudgea jasminoides, a tropical woody Rubiaceae. Plant Cell Tissue and Organ Culture 68: 271-276. 
VOGEL,A.I. 1971. Análise orgânica qualitativa. Edusp, São Paulo. WAGNER, H. \& BLADT, S. 1986. Plant drug analysis - a thin layer chromatography atlas. Spring-Verlag, Heidelberg. WIJNSMA, R., GO, J.T.K.A., VANWEERDEN, N., HARKES, P.A.A., VERPOORTE, R. \& SVENDSEN, A.B. 1984. Anthraquinones as phytoalexins in cell and tissue cultures of Cinchona species. Plant Cell Reports 4:241-244.
YOUNG, M.C.M., BRAGA, M.R., DIETRICH, S.M.C., BOLZANI, V.S., TREVISAN, L.M.V. \& GOTTLIEB, O.R. 1996. Chemosystematic markers of Rubiaceae. Opera Botanica Belgica 7:205-212.

ZAPPI, D. 2003. Revision of Rudgea (Rubiaceae) in Southeastern and Southern Brazil. Kew Bulletin 58:513-596. 